\title{
The European Circumstance and the Politics of Meaning: Not on Bread Alone Doth Man Liveth (Deut. 8:3; Mat 4:4)
}

\author{
Joseph H.H. Weiler*
}

Upon receiving the Charlemagne Prize in May 2016, Pope Francis poignantly asked: "Europe, what has happened to you?" The question is even more poignant today in the face of the rising tide of so-called populism, which can no longer be dismissed as peripheral or limited to a couple of countries with a short democratic tradition. It manifests itself in both widespread Euroscepticism and in a challenge to the foundational values of liberal democracy.

Those who believe that the answer can be found entirely in the realm of the material-unemployment or the uneven distribution of the deserts of Globalism-are mistaken. These economic factors are important, but they do not explain the appeal of populists in countries and strata of society which cannot be included in a discontent that stems from economic dissatisfaction alone. It is also an explanation that laughably reduces the human person to his or her material needs only. The issues of values and the spiritual wellbeing of the person are no less an important factor in answering Francis' question.

I want to postulate that the human condition is such that each of us-consciously or subconsciously_-seeks to satisfy not only material needs, but metaphysical ones too. Among them first and foremost, is the wish or need to give both significance and meaning to our short lives-a significance and meaning that goes beyond that which serves one's own self interests. Values play a role in satisfying that primordial drive. And it is here that we find a major deficit in the ways we have articulated and come to understand the "values of Europe."

What are these values? Again and again we face the Holy Trinity: Democracy, human rights, and the rule of law. Yes, Europe does stand for these values. And yes, we should never accept to live in a society which does not respect and honor these values. The metaphor of the Holy Trinity is more than an irony: Like the real Holy Trinity, they are three which are oneindivisible. You cannot have democracy without fundamental rights, as that would simply be a return to the tyranny of the majority. Hitler and Mussolini were hugely popular at their time and came to power democratically. A society cannot have human rights without the rule of law, etc., etc. For example, the idea of an illiberal democracy is ontologically an impossibility, an oxymoron.

But there is an aspect of the Holy Trinity, of these values, which is rarely discussed. Fundamental rights guarantee our liberties, but they give us no guidance on how to act under the canopy of such liberties. Democracy is a technology of governance-indispensable. But it does not tell us how to exercise democratic powers. A democracy of evil people will be evil, even if democratic. This is true for liberties and obviously for the rule of law. There can be pretty nasty laws, which do not necessarily violate fundamental rights but are nasty nonetheless.

The Holy Trinity of values provides the conditions for action-individual and collective-but not its content.

${ }^{\star}$ Professor, NYU School of Law.

(c) The Author(s) 2020. Published by Cambridge University Press on behalf of the German Law Journal. This is an Open Access article, distributed under the terms of the Creative Commons Attribution licence (https://creativecommons.org/licenses/by/4.0/), which permits unrestricted re-use, distribution, and reproduction in any medium, provided the original work is properly cited. 
They are a necessary, but not a sufficient, condition to satisfy the primordial quest for meaning and significance. Let me then mention three of the classical values which have disappeared from our public life that — in the past—catered just to that. We may wish to call them the Unholy Trinity of Values.

These values are to be found in three processes which began as reactions to the Second World War and have evolved over the last decades.

\section{A. The Demise of Patriotism as a Discipline of Love}

In the First Process. For reasons that are quite understandable, the very word patriotism became unprintable after the War, notably in Western Europe. Fascist regimes, among others, by abusing the word and the concept, had burned it from our collective consciousness. And in many ways, this has been a positive thing. But we also pay a high price for having banished this word-and the sentiment it expresses - from our psycho-political vocabulary. Because patriotism also has a noble side: The discipline of love and the duty to take care of one's homeland, people, neighbor and of accepting our civic responsibility toward the community in which we live. In reality, true patriotism is the opposite of fascism: "We do not belong to the State, it's the State that belongs to us," and we are responsible for it and what happens to it.

This kind of patriotism is an integral and indispensable part of the republican form of democracy. Today, we may call ourselves the Italian or French Republic or Bundesrepublik, but our democracies are no longer truly republican. There is the State, there is the government, and then there is "us."

We are like shareholders of an enterprise. If the directorate of the enterprise, called the Republic, does not produce political and material dividends, then we change managers with a vote during a meeting of shareholders called elections. If there is anything that does not work in our society, we go to the directors-as we do, for example, when our internet connection isn't working: "We paid [our taxes], and look at the terrible service they're giving us ...." The State is always the one responsible. Never us. It's a clientelist democracy that not only takes away our responsibility toward our society and our country, but also removes responsibility from our very human condition.

\section{B. The Culture of Rights and its Discontents-The Rule and Role of Law}

The second process - which helps to explain what happened to Europe-comes, once again, as a reaction to the War, and is paradoxical. We've accepted-both at the national and international levels-a serious and irreversible obligation rooted in our Constitutions to protect the fundamental rights of individuals, even against the political tyranny of the majority. At a more general level, our political-juridical vocabulary has become a discussion of legal rights. The rights of a German citizen are protected by our courts, and, above all, by the Constitutional Court. But they are also protected, by the Court of Justice of the EU in Luxembourg, and-again-by the European Court of Human Rights in Strasbourg. It is enough to make your head spin. And this is true for the other Member States.

Just think about how common it has become-in the political discourse of today-to speak more and more about rights, to try and turn any political action into a legal action about rights and entitlements, and to use the courts, again and again, to achieve our political objectives. It is enormously important. I would never want to live in a country in which fundamental rights are not effectively defended. But here too - as with the banishment of patriotism-we pay a dear price. Actually, we pay two prices. 
First and foremost, the noble culture of rights does put the individual at the center, but little by little-almost without realizing it - it turns him or her into a self-centered individual. It atomizes the individual because most fundamental right battles pose an individual and his or her liberties against the collective good.

And the second effect of this "culture of rights" - which is a framework all Europeans have in common-is a kind of flattening of political and cultural specificity of one's own unique national identity.

"Identity politics," like patriotism, is another unmentionable in our current political vocabulary. It has, indeed, a dark side which manifests itself in atavism, odious notions of "national purity" the pathological manifestation of which is ethnic cleansing. But like patriotism, there is also a deep value to which identity gives expression. Indeed, it derives from the most fundamental of fundamental rights in the European tradition - that of human dignity-which takes pride of place in our various constitutions and instruments protecting human rights.

The notion of human dignity - the fact that we have been created in the image of God or the secular Kantian equivalent-contains, at one and the same time, two facets. On the one hand, it means that we are all equal in our fundamental human dignity: Rich and poor, Italians and Germans, men and women, Gentile and Jew. On the other hand, recognizing human dignity means accepting that each of us is an entire universe, distinct and different from any other person. And the same is true for each of our societies. To deracinate the cultural specificity of each of our nations and societies is, in this sense, to compromise an essential element of our dignity. When this element of diversity is diminished or derided, we rebel.

And because-with only small differences of nuance-our supreme value as Europeans is our belief in the Holy Trinity of Rights, democracy and the rule of law-and thankfully this is the case-the specificities of our identities are seen to be devalued.

\section{Secularism}

The third process that explains what has happened to Europe is secularization. Let me be clear: This observation is not an evangelical rebuke. I do not judge a person based on his or her faith or lack thereof. And even though, for me, it is impossible to imagine the world without the Lord-The Holy Blessed Be He-I also know many religious people who are odious and many atheists of the highest moral character. But Europe has not only undergone a dramatic and rather rapid process of secularization, it has been accompanied by increasing manifestations of Christophobia, Islamophobia, and Antisemitism - a general contempt of religion and the religious.

This process also began with World War II. Who among us-after having seen the mountains of shoes from millions of assassinated children at Auschwitz-didn't ask the question: God, where were you?

The importance of secularism is in the fact that a voice which was at one time universal and ubiquitous - a voice in which the emphasis was on duty and responsibility and not only rights on personal responsibility in the face of what happens to us, our neighbors, our society, and not the instinctive appeal to public institutions-has all but disappeared from social praxis.

In Church, you do not hear about your entitlements from the State and others, but on your duty towards society and others. No politician today in Europe could, or would, repeat the famous Kennedy Inauguration speech of 1960: “Don't ask what your country can do for you but what you can do ...." Anything that goes wrong in our society is always the responsibility of others, not of us.

The Citizenship chapter of the European Treaties is a poignant example. They speak of rights and duties which the citizen enjoys and owes-but then no duties are ever mentioned. 
It is totally understandable why we had become suspicious of patriotism, of identity politics-seeing the abusive way they were instrumentalized in Europe's past. But we have thrown the baby out together with the bathwater. And into this void has stepped the new Populist with, oftentimes, the old abusive versions.

It is easy to understand the appeal of, say, nationalism: As a member of a national community, I have a past and a future beyond my individual self-interest. The national idiom emphasizes that which is special and unique, and as such, it becomes part of the identitarian asset of the individual. Calling on people's duty and responsibility empowers them and gives their action a meaning which goes beyond their self-interest. Above all, it imbues persons with respect and self-respect.

Our historical mistake was to fail to understand the huge importance of collective values and to adapt them to a modern progressive narrative which combined the so called Holy and Unholy Trinities of values.

Mussolini thrived on the politics of meaning with his slogan of "Dio, Patria, Famiglia." But his version of the Patria was dictatorial and fascist; of the Church hierarchical and mediatory; and the family was patriarchal and repressive.

There is a way of celebrating and respecting love of society and country, the idiom of liberal patriotism, of coupling rights with duties, of having a healthy self-respect to one's collective identity and culture which is not atavistic and chauvinist, and of exercising the best in the Christian heritage even if one has lost religious faith.

But that way is not "out there" as part of the program of mainstream politics. All we hear is a narrative of employment, and growth, and a more equitable distribution of economic deserts-of how better to manage our markets and our prosperity. All are incredibly valuable but fail to understand that not on bread alone does man liveth. Until we fill this void, the field will be left for the likes of Orban and his pals.

Cite this article: Weiler JHH (2020). The European Circumstance and the Politics of Meaning: Not on Bread Alone Doth Man Liveth (Deut. 8:3; Mat 4:4). German Law Journal 21, 96-99. https://doi.org/10.1017/glj.2019.103 